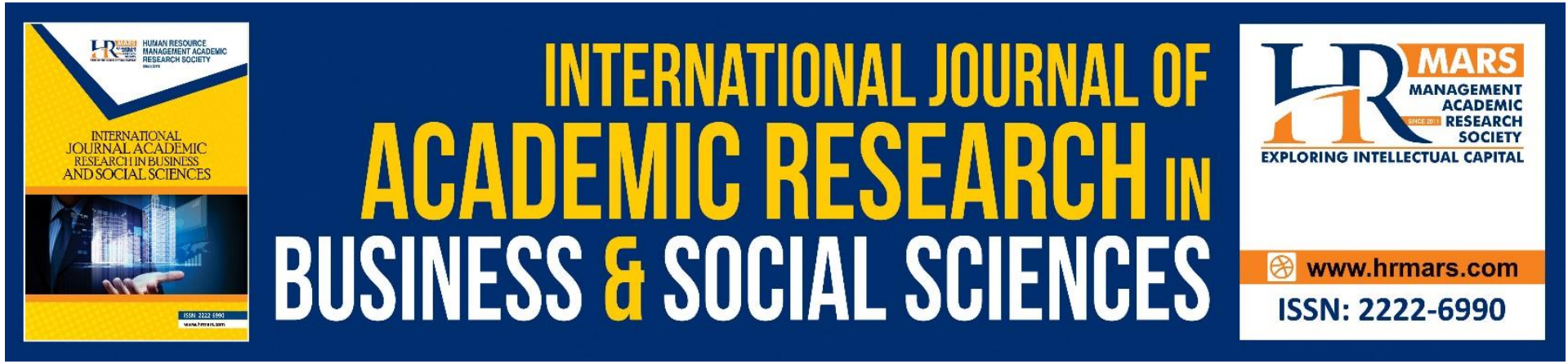

\title{
A Pilot Study of the Outcome-Based Education (Obe) Achievement and The Implementation of Self-Regulated Learning Strategies in Islamic Studies
}

Ahmad Firdaus Mohd Noor, Khairunnisa A Shukor, Nazirah Hamdan, Mukhamad Khafiz Abdul Basir, Mohamad Khairul Latif, Nur Afifah Saharudin, Ariyanti Adnan

To Link this Article: http://dx.doi.org/10.6007/IJARBSS/v11-i7/10584

DOI:10.6007/IJARBSS/v11-i7/10584

Received: 18 May 2021, Revised: 20 June 2021, Accepted: 07 July 2021

Published Online: 28 July 2021

In-Text Citation: (Noor et al., 2021)

To Cite this Article: Noor, A. F. M., Shukor, K. A., Hamdan, N., Basir, M. K. A., Latif, M. K., Saharudin, N. A., \& Adnan, A. (2021). A Pilot Study of the Outcome-Based Education (Obe) Achievement and The Implementation of Self-Regulated Learning Strategies in Islamic Studies. International Journal of Academic Research in Business and Social Sciences, 11(7), 1217-1227.

Copyright: (c) 2021 The Author(s)

Published by Human Resource Management Academic Research Society (www.hrmars.com)

This article is published under the Creative Commons Attribution (CC BY 4.0) license. Anyone may reproduce, distribute, translate and create derivative works of this article (for both commercial and non-commercial purposes), subject to full attribution to the original publication and authors. The full terms of this license may be seen

at: http://creativecommons.org/licences/by/4.0/legalcode

Vol. 11, No. 7, 2021, Pg. 1217 - 1227

Full Terms \& Conditions of access and use can be found at http://hrmars.com/index.php/pages/detail/publication-ethics 


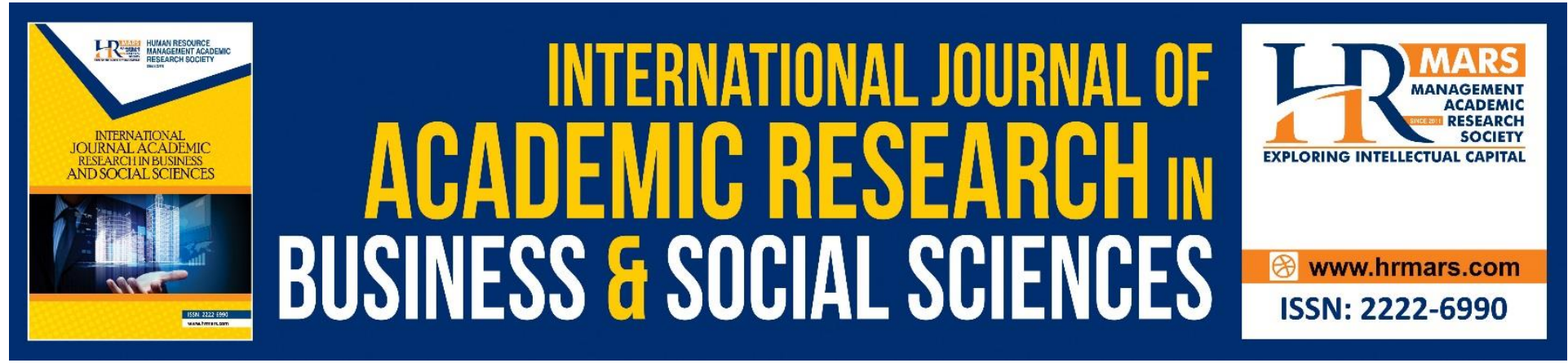

\title{
A Pilot Study of the Outcome-Based Education (Obe) Achievement and The Implementation of Self-Regulated Learning Strategies in Islamic Studies
}

\author{
Ahmad Firdaus Mohd Noor (PhD) \\ Academy of Contemporary Islamic Studies (ACIS), Universiti Teknologi MARA, Perak Branch, \\ Seri Iskandar Campus \\ Email: firdausnoor@uitm.edu.my
}

Khairunnisa A Shukor (PhD)

Academy of Islamic Civilization, Faculty of Social Sciences and Humanities, Universiti

Teknologi Malaysia, Skudai.

Nazirah Hamdan (PhD)

Academy of Contemporary Islamic Studies (ACIS), Universiti Teknologi MARA, Sarawak

Branch, Samarahan Campus

\section{Mukhamad Khafiz Abdul Basir}

Academy of Contemporary Islamic Studies (ACIS), Universiti Teknologi MARA, Perak Branch,

Seri Iskandar Campus

Mohamad Khairul Latif

Academy of Islamic Civilization, Faculty of Social Sciences and Humanities, Universiti

Teknologi Malaysia, Skudai.

Nur Afifah Saharudin, Ariyanti Adnan

Department of General Studies, Ungku Omar Polytechnic, Ipoh.

\begin{abstract}
OBE approach prepares the students to face the working world and life-long challenges. Therefore, it is important to explore the impact of self-approach in study as the OBE approach focuses on student-centered learning. Self-regulated strategies are found to fit this research framework. This study aims to measure the contribution of self-regulated learning on the achievement of OBE goals in Islamic Studies. Students who have taken Islamic Studies in a polytechnic has participated in this study. A questionnaire was distributed and data were
\end{abstract}


analysed using SPSS 25.0. The findings show that students' grade were low (Mean=2.23, $S D=1.77$ ), even the application of self-regulated learning strategies is high (Mean=5.10, $S D=0.89$ ). Six out of nine strategies reach high mean score (Mean $=\geq 5.00$ ); rehearsing, parsing, organising, critical thinking, learning with friends, and asking for help from others. The regression analysis found that self-regulated learning strategies contribute $13.9 \%$ towards the grade of Islamic Studies. Every strategy contributes less than $5 \%$ towards students' grade in Islamic Studies. Repetition technique has majorly contributed to the grade because students memorised Quranic verses and recited the daily prayers as practical tests. It is the third highly used by the students (Mean=5.70, SD=1.07), after organising (Mean=5.73, SD=0.85) and study with friends (Mean=5.94, SD=3.90). In conclusion, even self-learning strategies were applied by the students to achieve the OBE aims of Islamic Studies, they have minimal contribution towards the achievement of good grades among students.

Keywords: Obe, Self-Regulated Learning Strategies, Islamic Studies, Polytechnic

\section{Introduction}

The government's efforts in transforming the Polytechnic of the Ministry of Higher Education Malaysia are clearly stated in the Agenda of the Polytechnic Transformation Plan. This effort is a necessity where it is time the Polytechnic of the Ministry of Higher Education Malaysia is strengthened so that it can be the institution of choice for students to further their studies, along with other institutions of higher learning and produce graduates who can meet job prospects (Utusan Online, 2011). YAB Tan Sri Muhyiddin mentioned in his speech when officiating the Polytechnic Transformation Launching Ceremony 2010 at the Putrajaya International Convention Center:

"I believe the Polytechnic Transformation program launched today is an important effort towards improving the quality and strengthening of vocational and technical education in our country."

(Department of Polytechnic Studies, 2010)

Among the efforts recommended in helping this transformation, work is to improve the quality of learning and teaching by developing new approaches in improving students' academic performance. Datuk Mohlis Jaafar, Deputy Director General (Operations) of the Department of Polytechnic Studies, commented on teaching staff in improving the quality of teaching and learning and strengthening the development and research sector (Mohd. Rizal Azman Rifin, Berita Harian Online, tt). Mr Hj. Md. Nor Bin Yusof delivered the New Year's Message 2011 on quality aspects to improve the quality of teaching and learning of polytechnics throughout Malaysia by emphasising the Outcome-Based Education (OBE) approach:

"Through the Outcome-Based Education (OBE) approach, in line with the requirements of the Malaysian Qualifications Agency, polytechnics need to strengthen the relevance and responsiveness of the programs offered. The $O B E$ approach requires a shift from lecturer-centred learning to studentcentred learning. about $O B E$ needs to be fully appreciated so that effective teaching and learning can be carried out."

(Department of Polytechnic Studies, 2011)

Outcome-based Education (OBE) refers to an approach used in the teaching and learning process that emphasises the results and achievement of objectives of an academic course 
(Mohd Jailani Mohd Nor et al., 2005). OBE approach was first introduced by the Ministry of Higher Education Malaysia in 2010 (Yaman et al., 2012). With this, the OBE approach has started to be practised as an approach in student-centred teaching and learning activities. Barr et al (2008) also stated that OBE is an approach that focuses on outcomes after attending an academic course, but he also added features as one of the criteria in the OBE approach. It focuses on the achievement of outcomes as opposed to focusing on the process of achieving those outcomes (Mohd Jailani Mohd Nor et al., 2005). Thus, here it can be clarified that OBE is an approach in education that emphasises what students can do after they are taught (Maki, 2004; Huba \& Freed, 2010).

Given that OBE is a student-centred teaching and learning approach, Nor \& Zaharim (2007) translate the achievement of OBE goals as preparation for the world of work and being a member of society into three forms of outcomes; (1) knowledge, (2) attitude and (3) skills that can be applied in the subject of Islamic Studies. OBE requires students to have high selflearning strategies (Singh, 2008). A study conducted showed that educators try to develop self-learning strategies among students through teaching and learning strategies that meet OBE goals (Thusi, 2004). According to Usher \& Pajares (2008), self-learning strategies refer to metacognitive processes, a situation in which students review their thought processes, evaluate performance and plan other alternatives for success. Proactive students can control their learning processes, including cognitive, metacognitive, emotional and behavioural processes (Anthony, 2008; Fritz and Peklaj, 2011). High-performing students reflect the strategies they use, usually associated with high-ability strategies (Throndsen, 2011). An outstanding achievement indicates that students can control the learning environment. This process includes planning, monitoring and learning strategies (Johnson et al., 2011). A successful student requires both motivational beliefs and self-directed learning strategies (Kesici \& Erdogen, 2009). Motivation drives a person towards achieving goals because motivational beliefs allow students to learn at their own pace. Students 'motivational beliefs in terms of self-efficacy values and tasks are fundamental (Anthony, 2008). Self-efficacy can be affected by learning processes and learning outcomes; for example, students' career selfefficacy beliefs will increase when one is satisfied after mastering challenging tasks.

In conclusion, achievement of OBE goals is measured to see the extent to which the OBE approach is carried out. Since this OBE involves student-centred learning, it is vital to see selfapproach strategies in Islamic Studies.

\section{Research Objective}

Therefore, this study was conducted with the aim to study:

1) the level of achievement of OBE goals in Islamic Studies measured using the Outcomebased Assessment (OBA), which is the achievement grade of Islamic Studies I.

2) the level of implementation of self-learning strategies among students of Islamic Studies I.

3) the contribution of self-learning strategies in Islamic Studies grades.

\section{Research Design}

This study uses a pilot study to examine the achievement of OBE goals and self-learning strategies in the subject of Islamic Studies I using questionnaires distributed to students. 


\section{Study Sample}

The study involved 30 Semester II students in a polytechnic in Perak, who were randomly selected by criteria where they had already taken the subject of Islamic Studies I in the last semester.

\subsection{Study Instruments}

Achievement of OBE goals refers to the overall grade of Islamic Studies I, where each Course Learning Outcome (CLO) and Program Learning Outcome (PLO) needs to get a good percentage (above 50\%) as a benchmark that OBE goals are achieved. The following Table 3.0 is the PLO and CLO analysis statistics for the four departments involved in this study.

TABLE 3.0 STATISTICS OF PLO and CLO ANALYSIS By Each Department

\begin{tabular}{|c|c|c|c|c|c|c|c|c|c|c|c|c|c|c|c|c|}
\hline \multirow{3}{*}{$\begin{array}{l}\text { No } \\
\text {. }\end{array}$} & \multirow[t]{3}{*}{ Department } & \multirow{3}{*}{$\begin{array}{l}\text { Numb } \\
\text { er of } \\
\text { Stude } \\
\text { nts }\end{array}$} & \multicolumn{2}{|c|}{ CLO1 } & \multicolumn{2}{|c|}{$\mathrm{CLO} 2$} & \multicolumn{2}{|c|}{ CLO3 } & \multicolumn{2}{|c|}{ CLO4 } & \multicolumn{2}{|c|}{ CLO5 } & \multicolumn{2}{|c|}{ PLO1 } & \multicolumn{2}{|c|}{ PLO6 } \\
\hline & & & No & $\%$ & No & $\%$ & No & $\%$ & No & $\%$ & No & $\%$ & No & $\%$ & No & $\%$ \\
\hline & & & . & & . & & . & & . & & . & & . & & . & \\
\hline 1 & $\begin{array}{c}\text { Electrical } \\
\text { engineering } \\
\text { department }\end{array}$ & 130 & $\infty$ & ஓें & $\stackrel{\mathscr{\sim}}{\sim}$ & 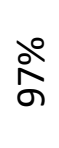 & $\underset{\neg}{\stackrel{\Xi}{\Im}}$ & ํํ & à & ㅇํㅅ & $\underset{\sim}{\sim}$ & ১̊ & 음 & $\stackrel{\text { ڤ̊ }}{\infty}$ & $\stackrel{\infty}{\sim}$ & ळ̊ \\
\hline 2 & $\begin{array}{c}\text { Civil } \\
\text { engineering } \\
\text { department }\end{array}$ & 337 & શั & $\stackrel{\circ}{\stackrel{\infty}{\infty}}$ & $\stackrel{\infty}{\vec{m}}$ & ㅇํ & $\stackrel{\sim}{m}$ & ळे & $\underset{\sim}{\stackrel{m}{*}}$ & ๙̊ำ & $\stackrel{\sim}{\sim}$ & 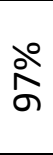 & $\stackrel{\infty}{m}$ & ๙̊ำ & $\stackrel{\infty}{m}$ & $\stackrel{\circ}{\frac{2}{n}}$ \\
\hline 3 & $\begin{array}{c}\text { Department } \\
\text { of } \\
\text { Commerce }\end{array}$ & 326 & $\stackrel{+}{\sim}$ & $\stackrel{\circ}{\stackrel{\infty}{\infty}}$ & $\stackrel{\text { nी }}{m}$ & ล̊ & $\underset{m}{\stackrel{9}{m}}$ & ஓ̊ & $\stackrel{\infty}{\circ}$ & ১̊ & $\vec{m}$ & 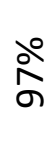 & $\stackrel{n}{m}$ & ๙̊ำ & $\underset{m}{\vec{m}}$ & ठ̊̊ \\
\hline 4 & $\begin{array}{l}\text { Department } \\
\text { of } \\
\text { Information }\end{array}$ & 265 & & & & & & & & & & & & & & \\
\hline & $\begin{array}{c}\text { Technology } \\
\text { and }\end{array}$ & & $\stackrel{b}{\sim}$ & mे & $\stackrel{\text { \& }}{\sim}$ & ஓু & $\stackrel{1}{N}$ & ๙ั & $\stackrel{\text { N }}{N}$ & ํํํ & $\underset{\sim}{\sim}$ & নे & $\underset{\sim}{\tilde{N}}$ & নे & 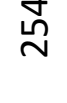 & ఫั \\
\hline & $\begin{array}{c}\text { Telecommu } \\
\text { nications }\end{array}$ & & & & & & & & & & & & & & & \\
\hline
\end{tabular}

Guidance

CLO1 Recite the verses of the Quran with tajweed and memorise the surahs given during the practical session

CLO2 Explain clearly the concept of knowledge in Islam so that it can be practised throughout life

CLO3 Strengthen the understanding of Tasawur Islam and Akidah to be used as a guide for life through analytical writing based on the situation described

CLO4 Exhibiting morals towards Allah SWT, the Prophet and fellow human beings and explaining moral issues based on a given situation

CLO5 Demonstrate how to perform worship in the life

PLO1 Knowledge

PLO6 Continuous Learning and Information Management Skills 
According to Table 3.0, all four departments achieved a satisfactory percentage of CLO and PLO. It can be said here that the Islamic Studies I classes involved have achieved the OBE goals that have been set for the Islamic Studies I course. Attitudes and skills, the overall grade of Islamic Studies I already includes all three forms of results in terms of theory (knowledge), morals (attitudes) and memorisation and practice of prayer (skills). Therefore, this study refers to the achievement grade of Islamic Studies I, where all three aspects of OBE have been included in the overall grade of Islamic Studies I.

To obtain the findings of the study on self-learning strategies, the Motivated Strategies for Learning Questionnaire (MLSQ) developed by McKeachie, Smith, Garcia and Pintrich (Duncan \& McKeachie, 2005), a way to identify the level of motivation and application of selflearning strategies, with a bit of modification so that it can be applied to students of Islamic Studies I. It consists of 81 items and is divided into two parts; motivation and self-learning strategies. Table 3.1 shows the division of the 81 items into their components.

TABLE 3.1 MLSQ Items

\begin{tabular}{|c|c|c|c|c|c|c|c|}
\hline \multicolumn{4}{|c|}{ Part 1: MOTIVATION } & \multicolumn{4}{|c|}{ Part 2: SELF -LEARNING STRATEGIES } \\
\hline $\begin{array}{l}\text { Compon } \\
\text { ents }\end{array}$ & Sub-scale & $\begin{array}{l}\text { Bill } \\
\text { Ite } \\
\mathrm{m} \\
\end{array}$ & No Item & Strategy & Sub-scale & $\begin{array}{l}\text { Bill } \\
\text { Ite } \\
\mathrm{m}\end{array}$ & No Item \\
\hline \multirow{3}{*}{$\begin{array}{c}\text { Value } \\
\text { Compon } \\
\text { ent }\end{array}$} & $\begin{array}{l}\text { Intrinsic Goal } \\
\text { Orientation }\end{array}$ & 4 & $\begin{array}{c}1,16,22 \\
24\end{array}$ & \multirow{5}{*}{$\begin{array}{l}\text { Cognitive } \\
\text { and } \\
\text { Metacogn } \\
\text { itive } \\
\text { Strategies }\end{array}$} & Repeating & 4 & $39,46,59,72$ \\
\hline & $\begin{array}{l}\text { Extrinsic Goal } \\
\text { Orientation }\end{array}$ & 4 & $\begin{array}{c}7,11,13 \\
30\end{array}$ & & Parsing & 6 & $\begin{array}{c}53,62,64,67, \\
69,81\end{array}$ \\
\hline & $\begin{array}{l}\text { Assignment } \\
\text { Value }\end{array}$ & 6 & $\begin{array}{l}4,10,17 \\
23,26,27\end{array}$ & & Organising & 4 & $32,42,49,63$ \\
\hline \multirow{2}{*}{$\begin{array}{l}\text { The } \\
\text { Hope } \\
\text { Compon } \\
\text { ent }\end{array}$} & $\begin{array}{l}\text { Control of } \\
\text { Learning Beliefs }\end{array}$ & 4 & $2,9,18,25$ & & $\begin{array}{l}\text { Critical } \\
\text { thinking }\end{array}$ & 5 & $\begin{array}{c}38,47,51,66, \\
71\end{array}$ \\
\hline & Self-confidence & 8 & $\begin{array}{c}5,6,12,15 \\
20,21,29 \\
31\end{array}$ & & Metacognitive & 12 & $\begin{array}{l}33,36,41,44, \\
54,55,56,57, \\
61,76,78,79\end{array}$ \\
\hline \multirow[t]{5}{*}{$\begin{array}{c}\text { Affective } \\
\text { Compon } \\
\text { ents }\end{array}$} & Anxiety Test & 5 & $\begin{array}{c}3,8,14,19 \\
28\end{array}$ & \multirow{4}{*}{$\begin{array}{c}\text { Resource } \\
\text { Managem } \\
\text { ent } \\
\text { Strategies }\end{array}$} & $\begin{array}{l}\text { Learning Time/ } \\
\text { Environment }\end{array}$ & 8 & $\begin{array}{l}35,43,52,65 \\
70,73,77,80\end{array}$ \\
\hline & & & & & Own effort & 4 & $37,48,60,74$ \\
\hline & & & & & $\begin{array}{l}\text { Study With } \\
\text { Friends }\end{array}$ & 3 & $34,45,50$ \\
\hline & & & & & $\begin{array}{l}\text { Asking Others } \\
\text { for Help }\end{array}$ & 4 & $40,58,68,75$ \\
\hline & Amount & 31 & & & mount & 50 & \\
\hline
\end{tabular}

\section{Study Analysis}

Since this study is quantitative, SPSS 17.0 was used to analyse the data. For the research objectives (1) and (2), frequency tests were conducted to find the mean score and standard deviation (Rahimi, 2004). 
TABLE 4.0 Mean Score Interpretation Table

\begin{tabular}{cc}
\hline Mean Score & Interpretation \\
\hline $5.01-7.00$ & High \\
$3.01-5.00$ & Average \\
$1.00-3.00$ & Low \\
\hline
\end{tabular}

In contrast, for the study's objective (3), the test used is the Multiple Regression Test to determine the contribution of variables. A normality test is required to test the distribution of Islamic Studies grade data I. Therefore, the Kolmogorov-Smirnova normality test is used (Piaw, 2006). According to Table 4.5, significant values exceeding 0.05 (Sig. $=0.323$ ) indicate that the data distribution for Islamic Studies grade $I$ is suitable to be used for multiple regression tests to test the objectives.

TABLE 4.1 Test of Normality

\begin{tabular}{cccc}
\hline Variabel & \multicolumn{3}{c}{ Kolmogorov-Smirnov $^{\text {a }}$} \\
\cline { 2 - 4 } & Statistics & Df & Sig. \\
\hline $\begin{array}{c}\text { Islamic Studies } \\
\text { Grade I }\end{array}$ & .323 & 30 & .000 \\
\hline
\end{tabular}

a. Lilliefors Significance Correction

\section{Findings}

The findings of the study are divided into two, namely descriptive data analysis and inferential data analysis.

Descriptive Data Analysis

Frequency tests were conducted to review objectives (1) and (2).

\section{Objective 1}

Assess the level of OBE achievement through the overall grade of Islamic Studies I

TABLE 5.0 Mean Grade Score of Islamic Studies I

\begin{tabular}{cccc}
\hline Variable & Mean & $\begin{array}{l}\text { Standard } \\
\text { deviation }\end{array}$ & Interpretation \\
\hline Grade of Islamic Studies I & 2.23 & 1.77 & Low \\
\hline
\end{tabular}

According to Table 5.0, the mean score for Islamic Studies grade I is 2.23 , and it is interpreted as low. It also indicates that the level of OBE achievement in Islamic Studies class is low. 
INTERNATIONAL JOURNAL OF ACADEMIC RESEARCH IN BUSINESS AND SOCIAL SCIENCES

Vol. 11, No. 7, 2021, E-ISSN: 2222-6990 @ 2021 HRMARS

Objective 2

To study the level of implementation of Islamic Studies self -learning strategies I

TABLE 5.1 Mean Score of Islamic Studies Self-Learning Strategies I

\begin{tabular}{lccc}
\hline \multicolumn{1}{c}{ Variable } & Mean & $\begin{array}{c}\text { Standard } \\
\text { deviation }\end{array}$ & Interpretation \\
\hline Repeating & 5.70 & 1.07 & High \\
Parsing & 5.09 & 1.04 & High \\
Organising & 5.73 & 0.85 & High \\
Critical thinking & 5.23 & 0.88 & High \\
Metacognitive & 4.76 & 0.93 & Average \\
Learning Time/ Environment & 4.55 & 0.84 & Average \\
Own effort & 3.59 & 1.12 & Average \\
Study With Friends & 5.94 & 3.90 & High \\
Asking Others for Help & 5.35 & 0.97 & High \\
\hline SELF-LEARNING STRATEGIES & 5.10 & 0.89 & High \\
\hline
\end{tabular}

Table 5.1 shows the mean score for each self-learning strategy the students used. Overall, the mean score of self-learning strategy is at a high level. Six strategies get a high level, namely rehearsing (5.70), parsing (5.09), organising (5.73), critical thinking (5.23), learning with friends (5.94) and asking for help from others (5.35). In comparison, three strategies get a low mean score, namely metacognitive (4.76), time/ learning environment (4.55) and self-effort (3.59).

\section{Contribution Analysis}

Contribution analysis using multiple regression test was conducted to see the contribution of self-learning strategies to Islamic Studies grade I.

\section{Objective 3}

To study the contribution of self-learning strategies to Islamic Studies I grade.

Multiple regression tests were used to test the extent to which self-learning strategies contributed to the grade of Islamic Studies I. This inferential analysis was conducted to examine objective 3 .

TABLE 5.2 Contribution of the Use of Self-Learning Strategies to the Grade of Islamic Studies

\begin{tabular}{l|c|c|c|c|c|c|c}
\hline \multicolumn{1}{c|}{ Variable } & $\mathrm{B}$ & Beta & $\mathrm{R}$ & $\mathrm{R}^{2}$ & $\begin{array}{c}\mathrm{R}^{2} \\
\text { Modified }\end{array}$ & $\mathrm{t}$ & Sig. \\
\hline Repeating & -0.493 & -0.300 & 0.090 & 0.057 & 0.057 & -1.662 & 0.108 \\
Parsing & -0.117 & -0.068 & 0.068 & 0.008 & -0.031 & -0.363 & 0.720 \\
Organising & -0.018 & -0.009 & 0.009 & 0.000 & -0.036 & -0.046 & 0.964 \\
Critical thinking & 0.016 & 0.008 & 0.008 & 0.000 & -0.036 & 0.043 & 0.966 \\
Metacognitive & 0.142 & 0.075 & 0.075 & 0.006 & -0.030 & 0.390 & 0.695 \\
Learning Time/ Environment & 0.256 & 0.122 & 0.122 & 0.015 & -0.020 & 0.652 & 0.520 \\
Effort & 0.275 & 0.174 & 0.174 & 0.030 & -0.004 & 0.937 & 0.357 \\
Study With Friends & 0.064 & 0.141 & 0.141 & 0.020 & -0.015 & 0.755 & 0.456 \\
Asking Others for Help & -0.179 & -0.098 & 0.098 & 0.010 & -0.026 & 0.523 & 0.605 \\
\hline
\end{tabular}

$F=2.149 \quad$ Sig. $F=0.74$ 
Multiple regression analysis as in Table 5.2 shows that the correlation between Islamic Studies with repeating (0.090), parsing (0.068), organising (0.009), critical thinking (0.008), metacognitive (0.075) and asking for help from others $(0.098)$ can be ignored, while the correlation of Islamic Studies grade I with time/learning environment (0.122), effort (0.174), peer learning (0.141) was at a low level. The t-test results showed that there was no significant relationship between Islamic Studies grades I with self -learning strategies.

The study's findings showed that 7 out of 9 strategies were found to contribute significantly to Islamic Studies grade I. The value of $\mathrm{R}^{2}$ showed that $5 \%$ (rehearsal), $0.8 \%$ (parsing), 0\% (organizing and critical thinking), 0.6\% (metacognitive), $1.5 \%$ (learning time/ environment), 3\% (effort), 2\% (learning with a friend) and 1\% (asking for help from others). Overall, self-directed learning strategies contributed $13.9 \%$ to Islamic Studies grade I.

\section{Discussion}

The level of CLO and PLO achievement of this course is measured based on the overall grade of Islamic Studies I. From the study findings that have been analysed, the analysis results show that the grade of Islamic Studies I is at a low level, and this also shows that the level of OBE achievement is also at a low level. However, the overall analysis of CLO and PLO achievement statistics is at a satisfactory level. Electrical Engineering students are $63 \%$.

The findings also show that the level of self-learning strategies in the subject of Islamic Studies $I$ is at a high level. Only three sub-scales reach a moderate level of use, namely metacognitive, time or learning environment and self-effort. It shows that respondents use fewer skills metacognitive, less regulating the time or place for learning, and less striving to achieve constructed goals. It can be said that they make less effort to achieve the goals that have been set at the beginning of learning. They also do not plan the appropriate time and place to study. Other learning strategies are at a high level, namely rehearsing, parsing, organising, critical thinking, self-effort, learning with peers and asking for help from others. Therefore, the findings of this study show that the students of Islamic Studies I;

i) rehearse the reading materials of Islamic Studies I

ii) parse the materials

iii) organise the materials such as storing them in a file

iv) strive to achieve the best in the Islamic Studies I course,

v) study with friends, and

vi) ask for help from others when there are problems in learning the Islamic Studies I course.

In terms of a contribution analysis, seven strategies have minimal contibutions to Islamic Studies, namely rehearsing, parsing, metacognitive skills, learning time/ environment, effort, learning with friends and asking for help from others while there are three strategies used in moderation. The strategy often used by Islamic Studies I students is to study with friends, rehearse and organise. However, rehearsal contributes the most in Islamic Studies and is followed by studying with friends. Students have to repeat the recitation of memorised verses and the recitation of prayers for practical tests. Islamic Studies Course I also involves group coursework and involves studying with friends. In conclusion, self-directed learning strategies contribute to achieving OBE goals, albeit at a low rate. 


\section{Conclusion}

Based on the study's findings, it can be said that self-learning strategies contribute relatively little to the achievement of Islamic Studies grade I. Although the level of self-learning strategies and high level of motivation can only help improve Islamic Studies I grade at a low rate. Therefore that OBE achievement is also at a low level. Although this study is only a pilot study, it can tell that other factors can improve the level of achievement of OBE goals other than self-learning strategies. These strategies have minimal contribution towards the achievement of good grades among students. However, students can practice some strategies to help raise the grade of Islamic Studies, namely studying with friends and rehearsing.

\section{References}

Anthony, Jr, A. R. (2008). Promoting Academic Motivation and Self-regulation: Practical Guidelines for Online Instruction. TechTrends, 52(3).

Amiza, Y., Noremy, C. A., \& Fadzlida, S. (2012). Kesediaan Pensyarah dalam Pelaksanaan Pengajaran dan Pembelajaran (PnP) Menggunakan Pendekatan Outcome-Based Education (OBE) di Politeknik Port Dickson. Referred on $30^{\text {th }}$ July 2012 from http://www.polipd.edu.my/v3/sites/default/files/20111007_Amiza_Noremy_Fadzlida. pdf

Barr, R. E., Krueger, T. J., and Aanstoos, T. A. (2006) 'Continuous Outcomes Assessment in an Introduction to Mechanical Engineering Course', 36 $6^{\text {th }}$ ASEE/IEEE Frontiers in Education Conference, S1E-9 - S1E-14.

Duncan, T. G., \& McKeachie, W. J. (2005).The Making of the Motivated Strategies for Learning Questionnaire. Educational Psychologist, 40: 117-128.

Jabatan Pengajian Politeknik. (2010). Teks Ucapan YAB Tan Sri Muhyiddin Bin Haji Mohd Yassin: Majlis Pelancaran Transformasi Politeknik. Referred on 30 $30^{\text {th }}$ July 2012 from http://politeknik.gov.my/webjpp2/files/Ucapan\%20Timbalan\%20Perdana\%20Menteri \%20Sempena\%20Majlis\%20Pelancaran\%20Transformasi\%20Politeknik\%20pada\%2025 0210.pdf

Jabatan Pengajian Politeknik. (2011). Warga Berinfomasi, Pemacu Tranformasi.Amanat Tahun Baru 2011: Ketua Pengarah Jabatan Pengajian Politeknik, Tn. Hj. Md. Nor Bin Yusof. Referred on $30^{\text {th }}$ July 2012 from http://politeknik.gov.my/dokumen/files/AMANAT\%20TAHUN\%20BAHARU\%20KP\%20v ersi\%20laman\%20web.pdf

Fritz, B. S., \&Peklaj, C. (2011). Processes of self-regulated learning in music theory in elementary music schools in Slovenia. International Journal of Music Education, 29(15).

Huba, M. E., \& Freed, J. E. (2000). Learner-Centred Assessment on College Campuses. Boston: Allyn\& Bacon.

Johnson, A. M., Azevedo, R., \&D'Mello, S. K. (2011). The Temporal and Dynamic Nature of Self-Regulatory Processes During Independent and Externally Assisted Hypermedia Learning. Cognition and Instruction, 29(4): 471-504.

Kesici, Ş., \& Erdogan, A. (2009). Predicting College Students' Mathematics Anxiety By Motivational Beliefs And Self-Regulated Learning Strategies. College Student Journal, 43(2): 631-642.

Killen, R. (2000). Outcomes-based education: Principles and possibilities. Unpublished manuscript, University of Newcastle, Faculty of Education

Maki, P. L. (2004). Assessing for Learning: Building a Sustainable Commitment across the Institution. Sterling, VA: Stylus. 
Jailani, M. N., \& Azami, Z. (2007). Perbandingan Pendekatan Pendidikan Sepadu dalam Pembelajaran Berasaskan Hasil (OBE) dengan Model Pendidikan Islam. Architectural and Engineering Education Seminar.

Jailan, M. N., Hamzah, N. H. B., \& Hamodi, W. B. (2005). Pembelajaran Berasaskan Hasil: Prinsip dan Cabaran. Effective Teaching and Learning Seminar.

Rahimi, N. M. N. Y. (2004). Kemahiran Mendengar Bahasa Arab: Satu Kajian di Sekolah Menengah Kerajaan Negeri. Universiti Kebangsaan Malaysia, Bangi.

Singh, P. (2008). Video-based Self-regulated Learning Strategies to Attain Metacognitive Consonance: A Hybrid Model. Education Association of South Africa, 20(3).

Throndsen, I. (2011). Self-regulated Learning of Basic Arithmetic Skills: A Longitudinal Study. British Journal of Educational Psychology, 81: 559-578.

Thusi, Z. E. (2004). Are We Developing Self-Regulated Learners in Grade Mathematics Classrooms: A Case Study Conducted At A High School in Kwa-Zulu Natal. Dissertation. Master of Education in Kwazulu-Natal University.

Usher, E. L., \& Pajares, F. (2008). Self-Efficacy for Self-Regulated Learning: A Validation Study. Educational and Psychological Measurement, 68(443).

Utusan Online. (2011). Politeknik Perlu Diperkasa, Jadi Pilihan Lepasan SPM. Referred on $30^{\text {th }}$ July 2012 from

http://www.utusan.com.my/utusan/info.asp?y=2011\&dt=0525\&pub=Utusan_Malaysi a\&sec=Kampus\&pg=ka_03.htm 